\title{
Ethnobotanical investigation on medicinal plants used against human ailments in Erkowit and Sinkat areas, Eastern Sudan
}

\author{
MANAR ADAM ${ }^{1}$, ABDEL AZIM AHMED ${ }^{2}$, AHMED YAGI ${ }^{3}$, SAKINA YAGI $^{1, \bullet}$ \\ ${ }^{1}$ Department of Botany, Faculty of Science, University of Khartoum, P.O. Box 321, Al Jamaa Street, Khartoum, Sudan. \\ Tel./fax.: +2499-15030004, `email: sakinayagi@gmail.com \\ ${ }^{2}$ Department of Biology, Faculty of Science, Universitas Albaha. Alaqiq, 65779-7738, Saudi Arabia \\ ${ }^{3}$ Department of Health Sciences, Khawarizimi International College. P.O. Box: 25669, Al Shahama Rd, United Arab Emirates
}

Manuscript received: 23 April 2020. Revision accepted: 23 June 2020

\begin{abstract}
Adam M, Ahmed AA, Yagi A, Yagi S. 2020. Ethnobotanical investigation on medicinal plants used against human ailments in Erkowit and Sinkat areas, Eastern Sudan. Biodiversitas 21: 3255-3262. The present study provides ethnobotanical data for the traditionally used medicinal plants of Erkowit and Sinkat, Eastern Sudan. The survey data were collected from 53 traditional healers through a survey carried out in February-December 2018. Fifty-eight plant species represent 34 flowering families and one Parmeliaceae lichen that are used for therapeutic purposes in the selected area. The families of highest prevalence were Euphorbiaceae ( 8 species) followed by Leguminosae (7 species). To validate information on the use of plants,: Use Value (UV), Fidelity Level (FL), and Informants' Consensus Factor (ICF) were applied. The most commonly used species was Adansonia digitata with a UV of 0.89. The majority of the informants agreed on the use of Oxalis anthelmintica to treat anemia and Psidium guajava in the treatment of tuberculosis and cough, with a very high FL (92\% and 91\% respectively). All informants agreed on the effectiveness of Withania somnifera in treating breast inflammation and cancer, with top ICF of 1 . These medicinal plants play an important role in the available healthcare provision in the study area. This preliminary study should be further continued into scientific assessment of their therapeutic use and safety through different biological activity tests and toxicological properties.
\end{abstract}

Keywords: Eastern Sudan, Erkowit, folklore medicine, medicinal plants, Sinkat, traditional use

Abbreviations: FL: Fidelity Level, ICF: Informants’ Consensus Factor, UV: Use Value, RSHS: Red Sea Hills State

\section{INTRODUCTION}

Diverse medicinal plants are used in the traditional healing practice and health promotion in Sudan, a country with more than forty million inhabitants, culturally diverse, and scattered over various terrains and climates (World Population on Prospects 2017). Sudan claims wealth of folklore medicine interwoven with the socio-economic, spiritual, rural, and tribal life and as a blend of Egyptian, Indian, Arabian, East, and West African cultural practices which over time have acquired a local mainstay identity. Based on religious and cultural background, indigenous knowledge, and empirical experience, the traditional herbal medicine application in Sudan is reflected differently in the different ethnic groups' practices, be it ritual, ceremonial, or healing. Consequent to centuries of folklore medicine and empirical knowledge, herbal medicine constitutes the main treatment for a high percentage of the population, significant proportion of it is nomadic. In addition, by virtue of economic factors and those in nomadic lifestyle, most of the population has limited access to standard mainstream medical care (Karar and Kuhnert 2017; Issa et al. 2018).

Within the immense diversity of plants, Sudan harbors an asset of flora of significant medicinal and economic importance. Among the flora in the country, records show that of the 3137 documented species of flowering plants in
Sudan, $15 \%$ are endemic to the country and that the documented flora are spread along 170 families and 1280 genera (Khalid et al. 2012). However, the country is not yet set up to actively promote products from its huge resource for a share in the rapidly evolving national and global market.

Of the flora of Eastern Sudan, those in the Erkowit and Sinkat areas share a floral gradient with Sahel zone and the Afromontane domain in addition to some with Mediterranean affinities (Vetaas et al. 2012). However, medicinal and economic exploitation of plants in this region is limited due to a lack of documented information, though there have been a few ethnobotanical studies of these plants, one reference being 'The Medicinal plants of Erkowit' by El-Ghazali (1986). Other factors that seem to have negatively influenced sustenance of local traditional knowledge include globalization, modernization, migration, and new healthcare systems. Thus far, the documentation maintains a repertoire of traditional healing skills and knowledge paving the way for future research on medicinal plants potential, aiming at safety, standardization and validation of their use (Bunalema et al. 2014) and towards the initiation of promising drug screening projects (Faruque et al. 2018). The objective of the present study was therefore to document the traditional knowledge of medicinal plants and their uses by local healers in the Erkowit and Sinkat areas, Eastern Sudan. 


\section{MATERIALS AND METHODS}

\section{Study area}

The present study was conducted in Erkowit $\left(18^{\circ} 42^{\prime} 0^{\prime \prime}\right.$ North, $37^{\circ} 0^{\prime} 0^{\prime \prime}$ East) and Sinkat (18 $50^{\circ} 14^{\prime \prime}$ North, $36^{\circ}$ 49' 58" East) areas, situated in Red Sea Hills State (RSHS), Eastern Sudan (Figure 1). The RSHS covers an area of approximately 125,000 square kilometers where the three main ecological zones could be characterized as the coastal plain, the RSH (3400-4200ft), and the Western plains (Vetaas et al. 2012). The seasonality of precipitation in these regions, namely in winter and summer, is bound to the combination of altitude, physiography, and proximity to the Red Sea $(45 \mathrm{~km})$ where the mean annual rainfall rarely exceeds $150 \mathrm{~mm}$ with temperature range of $10^{\circ} \mathrm{C}$ to $25^{\circ} \mathrm{C}$ during daytime in the course of the year. As to soil, the major area is rocky but there are sandy alluvial plains characterized by high salinity, especially in the coastal area (Manger 2001).

Livelihood in this region is based on livestock, especially camels, raised by the main tribe of Hadendowa who are a subdivision of the main tribe of Beja. Hadendowa people lead a nomadic lifestyle, with their classical shelters of hemispherical or rectangular tents made of straw mats laid over a wooden frame, are adapted to their lifestyle of movement as known camel traders traveling up and down the Red Sea area from Egypt to Eritrea. They also trade their crafts of straw mats and woolen rugs or charcoal and firewood for food. As the area is generally dominated by very rocky and mountainous terrain, it leaves few plots suitable for growing some vegetables like potatoes, carrots, cabbage, and tomato. Hadendowa groups were subjected to continuous famines due to the frequent lack of political entitlement from the Governments during drought periods with consequent deficiency of vital nutritional elements and malnutrition diseases including stunted growth, eye problems, diabetes, and heart diseases (Manger 2001).

\section{Procedures}

\section{Data collection and plant identification}

Using a structured questionnaire during the study period February-December 2018, in Erkowit and Sinkat, local healers were approached through some of the educated people who explained to them in the Hadendowa language the purpose and methods of the study, and consequently, the healers gave their informed consent. The semistructured questionnaire included different diseases; vernacular names of each medicinal plant and part, mode of preparation, and routes of administration. Qualitative ethnobotanical data were collected from 53 practicing people (26 from Sinkat and 27 from Erkwoit) aged 20-65 years old. During the surveys in the mountains in Erkowit and the valleys in Sinkat, herbarium specimens were collected and later deposited at the Botany Department, Faculty of Science, University of Khartoum, Sudan. Plant identification was done using keys of standard floras such as Maydell (1990), Elamin (1990), Hutchinson et al. (2014), Darbyshire et al. (2015). The botanical names and plant families are given according to the standards of the plant list (www.ipni.org/).

\section{Data analysis}

Data analysis was carried out by using both the classical ethnobotanical systematic investigation and a numerical quantitative approach. The use-value (UV), a quantitative measure for the relative importance of species known locally, was calculated as follows:

$$
\mathrm{UV}=\sum \mathrm{U}_{\mathrm{i}} / \mathrm{n}
$$

Where:

$\mathrm{U}_{\mathrm{i}}$ is the number of use-reports cited by each informant for a given species and $n$ refers to the total number of informants. Use values are high when there are many usereports for a plant (Srithi et al. 2009).

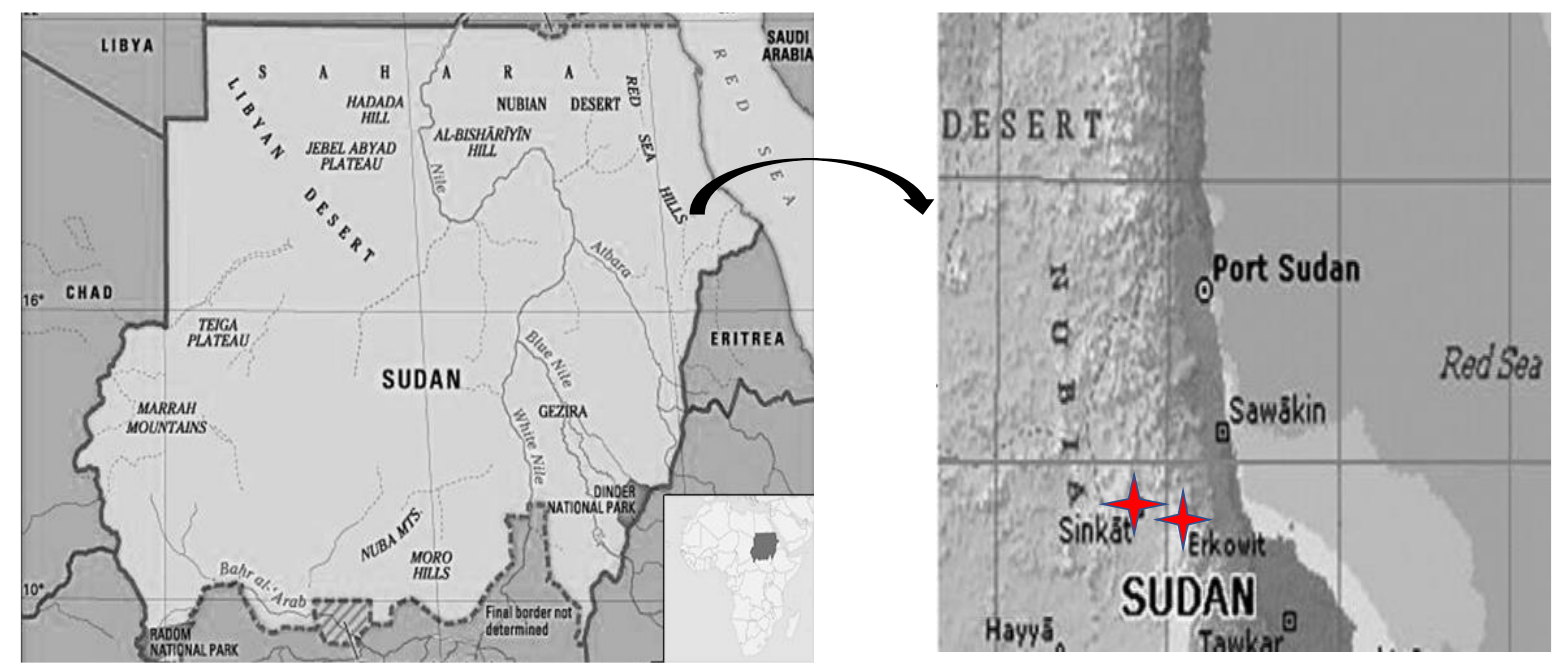

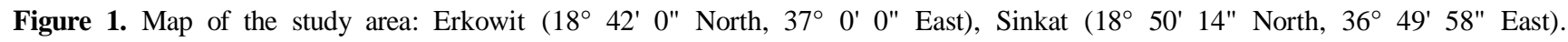
https://africa2trust.com/countryfacts/?1=1\&c=15 
The level of homogeneity among information provided by different informants was calculated by the informants' consensus factor (ICF) using the following formula:

$$
\mathrm{ICF}=\mathrm{N}_{\mathrm{ur}}-\mathrm{N}_{\mathrm{t}} /\left(\mathrm{N}_{\mathrm{ur}}-1\right)
$$

Where:

$\mathrm{N}_{\mathrm{ur}}$ : number of use reports from informants for a particular plant-use category

$\mathrm{N}_{t}$ : number of taxa or species that are used for that plant use category for all informants.

ICF values range between 0 and 1 , where ' 1 ' indicates the highest level of informant consent (Trotter and Logan 1986)

Fidelity level (FL), referred to the most preferred species used in treatment of a specific ailment, was calculated as

$$
\mathrm{FL}(\%)=\left(\mathrm{N}_{\mathrm{p}} / \mathrm{N}\right) \times 100
$$

Where:

$\mathrm{N}_{\mathrm{p}}$ : number of informants that claim a use of a plant species to treat a particular disease

$\mathrm{N}$ : number of informants that use the plants as a medicine to treat any given disease (Friedman et al. 1986)

\section{RESULTS AND DISCUSSION}

\section{Medicinal plants and the associated knowledge}

Our assessment of the knowledge of the traditional medicinal plants use was carried out by interviewing the informants. They were predominantly men (79\%), all of whom were practicing traditional healing as a secondary job. All informants referred their knowledge to information passed on through generations by word of mouth and cultural practices, and this was the foundation for the healthcare provision and other activities that maintained the society and conserved the knowledge. Furthermore, the informants stated that there was a cross-transfer of knowledge and experience between villagers and other groups. Similar to the earlier generations the illiteracy was still widespread in the study area where the rate was $66 \%$ among the informants in the age groups between 40 and 80 years old. However, among the rest of the informants, those in the age groups between 20 and 30 had received some education estimated as $19 \%$ at primary and $15 \%$ at secondary levels (Table 1).

\section{Medicinal plants diversity and habitat}

The diversity of medicinal plants in the present study is characterized by 58 plant species representing 34 flowering families and one lichen species belonging to Parmeliaceae (Table 2). Of the plants studied, the most diverse is the family Euphorbiaceae, comprising the largest number of species (8 spp.), followed by Leguminosae (7 spp.), Malvaceae (5 spp.), Crassulaceae and Solanaceae (3 spp. each) and Lamiaceae and Zygophyllaceae (2 spp. each). However, the remaining families (28) were less diverse, being represented each by only one species.

The majority of medicinal plants were collected from wild habitat $(85 \%)$ and were comprised mostly by herbs $(73 \%)$, to a lesser extent by trees $(16 \%)$, shrubs $(9 \%)$, and least represented were lichens constituting only $2 \%$ (Table $3)$. Concerning, the rest, they were either cultivated as in the case of Psidium guajava (2\%), or purchased (13\%) in the herbs market, which included fruit pulp of Adansonia digitata, fruit peel of Punica granatum, leaves and fruits of Grewia spp., seeds of Coriandrum sativum and Trigonella foenum-graecum as well as Melaleuca alternifolia leaves.

Parts of the studied medicinal plants, preparation, and administration

All plant parts could be used for treatment, with leaves being the parts mostly applied (48\%) followed by the whole plant $(23 \%)$, fruit $(12 \%)$, seed $(4 \%)$, stem/stem bark (7\% each), root and bulb (3\% each) (Figure 2 ).

Remedies were mostly administrated orally $(68 \%)$, as raw $(10 \%)$ or in the form of potion prepared by maceration $(15 \%)$, infusion $(22 \%)$, or decoction $(8 \%)$. Topical application (32\%) was applied as powder (54\%), smoke $(2 \%)$, and poultices $(6 \%)$ or as a wash and mouth rinsing (3\%) (Table 4).

Table 1. Demographic characteristics of the informants

\begin{tabular}{llcc}
\hline & & Number & $\begin{array}{c}\text { Percentage } \\
(\boldsymbol{\%})\end{array}$ \\
\hline Gender & Women & 11 & 21 \\
& Men & 42 & 79 \\
Age & $20-39$ & 18 & 34 \\
& $40-59$ & 24 & 45 \\
Educational level & $\geq 60$ & 11 & 21 \\
& & & \\
& Illiterate & 35 & 66 \\
& Primary school & 10 & 19 \\
& Secondary high school & 8 & 15 \\
\hline
\end{tabular}

Table 3. Growth habit of the wild, cultivated and purchased medicinal plants in the study area

\begin{tabular}{llll}
\hline Plant habit & Wild & Cultivated & Purchased \\
\hline Herb & $44(85 \%)$ & $1(2 \%)$ & $7(13 \%)$ \\
Shrub & $32(73 \%)$ & - & $2(29 \%)$ \\
Tree & $4(9 \%)$ & $1(100 \%)$ & $3(42 \%)$ \\
Lichen & $7(16 \%)$ & - & $2(29 \%)$ \\
\hline
\end{tabular}


Table 2. Medicinal plants used by traditional healers collected from Erkowit and Sinkat areas, Sudan

\begin{tabular}{|c|c|c|c|c|c|c|c|}
\hline Species/family/voucher no. & $\begin{array}{l}\text { Vernacular } \\
\text { name }\end{array}$ & Habit & Use value & Part used & Application & Preparation mode & $\begin{array}{l}\text { Adm. } \\
\text { mode }\end{array}$ \\
\hline Acacia etbaica Schweinf., Leguminosae, AE/E18 & Garad & Tree & 0.5 & Fruit & Cough & Infusion & Oral \\
\hline Acacia seyal Delile, Leguminosae, AS/S18 & Talih & Tree & 0.69 & Fruit & Diabetes & Maceration & Oral \\
\hline Adansonia digitata* L., Malvaceae AD/E18 & Gongulase & Tree & 0.89 & Fruit pulp & Diarrhea & Maceration & Oral \\
\hline Agrimonia eupatoria L., Rosaceae, AE/E18 & Shokran & Herb & 0.27 & Whole plant & Tuberculosis & Raw powder & Oral \\
\hline Aloe sinkatana Reynolds, Xanthorrhoeaceae, AS/E18 & Kalandoy & Herb & 0.13 & Leaf & $\begin{array}{l}\text { Wounds } \\
\text { Headache }\end{array}$ & $\begin{array}{l}\text { Powder sprinkled in wound } \\
\text { Smoke fumigant }\end{array}$ & $\begin{array}{l}\text { Topical } \\
\text { Topical }\end{array}$ \\
\hline Anastatica hierochuntica L., Brassicaceae, AH/S18 & Um Kafait & Herb & 0.32 & Whole plant & Skin allergies and sore & Dried, mixed with oil and rubbed & Topical \\
\hline Aristolochia bracteolata Lam., Aristolochiaceae, AB/S18 & Yahemyay & Herb & 0.13 & Leaf & $\begin{array}{l}\text { Hypertension } \\
\text { Dysentery }\end{array}$ & $\begin{array}{l}\text { Maceration } \\
\text { Maceration and mixed with } \\
\text { yogurt }\end{array}$ & $\begin{array}{l}\text { Oral } \\
\text { Oral }\end{array}$ \\
\hline Artemisia absinthium L., Asteraceae, AA/S18 & Dimseesa & Herb & 0.38 & $\begin{array}{l}\text { Whole plant } \\
\text { Root }\end{array}$ & $\begin{array}{l}\text { Urinary tract infections } \\
\text { Diabetes }\end{array}$ & $\begin{array}{l}\text { Maceration } \\
\text { Maceration }\end{array}$ & $\begin{array}{l}\text { Oral } \\
\text { Oral }\end{array}$ \\
\hline Azadirachta indica A. Juss., Meliaceae,AI/S18 & Neem & Tree & 0.83 & Leaf & Malaria & Powder added to lemon juice. & Oral \\
\hline Balanites aegyptiaca (L.) Delile, Balanitaceae, BA/E18 & Shashut & Tree & 0.66 & Leaf & Tuberculosis & Infusion & Oral \\
\hline Calotropis procera (Aiton) Dryand., Asclepiadaceae, CP/E18 & Ambras & Shrub & 0.50 & Leaf & Rheumatism & $\begin{array}{l}\text { Powder mixed with sesame oil and } \\
\text { rubbed }\end{array}$ & Topical \\
\hline \multirow[t]{2}{*}{$\begin{array}{l}\text { Chrozophora oblongifolia (Delile) A. Juss. ex Spreng, } \\
\text { Euphorbiaceae, CO/E18 }\end{array}$} & Ramtouk/Sumah/tirba & Herb & 0.13 & Leaf & Skin allergies & Maceration and taken as bath & Topical \\
\hline & & & & & Malaria & Infusion & Oral \\
\hline Cissus quinquangularis Chiov., Vitaceae, CQ/E18 & Katut & Climber & 0.05 & Leaf & Skin rashes and allergies & Powder rubbed locally & Topical \\
\hline Citrullus colocynthis (L.) Schrad., Cucurbitaceae, CC/E18 & Handal & Herb & 0.05 & Seed & Skin blemishes & Maceration and taken as bath & Topical \\
\hline Coleus barbatus (Andrews) Benth., Lamiaceae, CB/E18 & Khahab & Herb & 0.66 & Whole plant & Skin allergies & Smoke fumigant & Topical \\
\hline \multirow[t]{2}{*}{ Corchorus depressus (L.) Stocks, Malvaceae, CD/E18 } & Hayaoyanyet & Herb & 0.13 & Leaf & $\begin{array}{l}\text { Malaria } \\
\text { Anemia }\end{array}$ & $\begin{array}{l}\text { Maceration } \\
\text { Maceration }\end{array}$ & $\begin{array}{l}\text { Oral } \\
\text { Oral }\end{array}$ \\
\hline & & & & & Gum inflammation & Infusion used as mouth rinsing & Topical \\
\hline Coriandrum sativum* L., Apiaceae, CS/S18 & Kasspara & Herb & 0.22 & Seed & Dysentery & Decoction & Oral \\
\hline $\begin{array}{l}\text { Crassula pentandra (Royle ex Edgew.) Schoenl., } \\
\text { Crassulaceae, CP/S18 }\end{array}$ & Kalanjo & Herb & 0.09 & Leaf & Skin rashes & Powder rubbed locally & Topical \\
\hline \multirow[t]{2}{*}{ Datura stramonium L., Solanaceae, DS/S18 } & Datura & Herb & 0.05 & Leaf & Hemophilia and bleeding & $\begin{array}{l}\text { Powder added in a very tiny amount } \\
\text { to water and drunk }\end{array}$ & Oral \\
\hline & Shokaleeb & Herb & 0.05 & Whole plant & Rheumatism & $\begin{array}{l}\text { Powder mixed with } \\
\text { Sesame oil and rubbed }\end{array}$ & Topical \\
\hline $\begin{array}{l}\text { Euphorbia candelabrum Tremaux ex Kotschy, Euphorbiaceae, } \\
\text { EC/E18 }\end{array}$ & Zagoum & Tree & & Stem & Tuberculosis & Few drops of latex diluted in water & Oral \\
\hline Euphorbia heterophylla L., Euphorbiaceae, EH/E18 & Labna & Herb & 0.05 & Whole plant & Eczema & Powder rubbed locally & Topical \\
\hline \multirow[t]{3}{*}{ Euphorbia hirta L., Euphorbiaceae, EH/S18 } & Ataib & Herb & 0.05 & Whole plant & Constipation & Infusion & Oral \\
\hline & & & & & Malaria & Infusion & Oral \\
\hline & & & & & Asthma & Infusion & Oral \\
\hline $\begin{array}{l}\text { Euphorbia polycantha Schweinf. Ex Pax, Euphorbiaceae, } \\
\text { AP/E18 }\end{array}$ & Zagoum & Shrub & 0.07 & Stem & Wound & Latex applied locally & Topical \\
\hline Euphorbia triaculeata Forssk., Euphorbiaceae, AT/S18 & Um Libaina & Shrub & 0.10 & Stem & Syphilis, gonorrhea & Latex applied locally & Topical \\
\hline Fagonia indica Burm.f., Zygophyllaceae, FI/E18 & Um Shouk & Herb & 0.59 & Whole plant & Toothache & Filling tooth cavity with powder & Topical \\
\hline
\end{tabular}


Grewia bicolor* Juss., Malvaceae, GB/S18

Grewia tenax* (Forssk.) Fiori, Malvaceae, GT/S18

Basham Albayad Shrub 0.05

Root

Wounds
Bilharzia

Fruit

Anemia

Jaundice

Malaria

Hyphaene thebaica (L.) Mart., Arecaceae, HT/E18

Doam

Tree 0.63

Fruit

Hypertension

Jatropha curcas L., Euphorbiaceae, JC/E18

Kalanchoe glaucescens Britten, Crassulaceae, KG/E18

Alambeet

Malut

Leucas nubica Benth., Lamiaceae, LN/S18

Mayoub

Malva parviflora L. Malvaceae, MP/E18 Humaad

Melaleuca alternifolia* (Maiden \& Betche) Cheel, Myrtaceae, Shahi

MA/S18

Moringa oleifera Lam., Moringacea

Moringa

Ocimum basilicum L., Labiatae, OB/S18

Raihan

Oxalis anthelmintica A.Rich., Oxalidaceae, OA/E18

Homaid

Pancratium tortuosum Herb., Amaryllidaceae, PT/E18

Basal sageer

Parmotrema ultralucens (Krog) Hale, Parmeliaceae, PU/S18 Abahagaib

$\begin{array}{lll}\text { Shrub } & 0.81 & \text { Leaf }\end{array}$

$\begin{array}{llll}\text { Shrub } & 0.05 & \text { Leaf Diabetes } \\ \text { Herb } & 0.78 & \text { Whole plant Jaundice }\end{array}$

Herb $\quad 0.78$

Whole plant Jaundice

Tree 0.23 Leaf Fever

Psidium guajava L., Myrtaceae, PG/S18

Gwava

Shrub $\quad 0.09$

Herb 0.05

Leaf Anemia

$\begin{array}{ll}\text { Herb } & 0.77 \\ \text { Herb } & 0.88\end{array}$

Leaf Jaundice

Kidney disorder

Whole plant Anemi

Lichen $\quad 0.32 \quad$ Whole plant Skin allergies and sore

Punica granatum* L., Lythraceae

Romman

Shrub/ 0.81

cultivated

Leaf
Leaf

Tuberculosis

Cough

Dysentery

Shrub $\quad 0.09$

Fruit pe

Salicornia fruticosa (L.) A.J.Scott, Amaranthaceae, SF/E18 Salvadora persica L., Salvadoraceae, SP/S18

Senna occidentalis (L.) Link, Leguminosae, SO/E18

Hamad

Senna alexandrina Mill., Leguminosae, SA/E18

Sangasanga

Herb $\quad 0.05$

Stem biarrhoea

Shrub $0.22 \quad$ Fruit Cough

Herb 0.05 Leaf Toothache

Ambarkwi Herb 0.09

Leaf

Skin allergies and sore

Infusion

Poultice applied to wounds

Infusion Oral

Maceration

Infusion

Infusion

Ora

Decoction after removing the crust Oral

Powder sprinkled in wound Topical

Infusion

Infusion

Poultice applied to wound

Poultice

Fresh leaves are eaten

Oral

Infusion

Infusion

Infusion

Maceration

Oral

Powder mixed with sesame oil Topical

Decoction

Maceration

Decoction

Infusion

Infusion

Infusion

Eaten raw

Eaten raw

Filling tooth cavity with powder

Powder mixed with sesame oil $\quad$ Topical

and rubbed

Diabetes

Maceration

Senna obtusifolia (L.) H.S.Irwin \& Barneby, Leguminosae, Anotelai

Herb $\quad 0.13 \quad$ Leaf

Malaria

$\mathrm{SO} / \mathrm{S} 18$

Anotelai Herb $0.13 \quad$ Lea

Skin allergies and sore

Decoction

Oral

Powder mixer

Topical

Solanum schimperianum Hochst, Solanaceae, SS/E18

Domhindib, Hantitrob Herb 0.79

Leaf

Wounds

Poultice appie

Wound

Topical

Solenostemma argel (Delile) Hayne, Apocynaceae, SA/E18

Aradib

Stomachac

Infusion

Maceration

Mecoction

Fruit Malaria

Tamarindus indica $\mathrm{L}$., Leguminosae, TI/S18

Amab

Tree $\quad 0.09$

Trianthema portulacastrum L., Aizoaceae, TP/S18

Tribulus terrestris L., Zygophyllaceae, TT/S18

Trigonella foenum-graecum* L., Leguminosae

Raba

Herb $\quad 0.77$

Whole plant Headache

Decoction
Infusion

Infusion

Leaf \& stem Urinary tract infections Decoction

$\begin{array}{lll}\text { Shishkel/diraisa } & \text { Herb } & 0.18 \\ \text { Hilba } & \text { Herb } & 0.77\end{array}$

Umbilicus botryoides Hochst. ex A Rich., Crassulaceae, UB/E18 Buscola

Urginea grandiflora Baker, Asparagaceae, UG/E18 Basal kabeer

Withania somnifera (L) Dunal, Solanaceae, WS/E18

Basal kabeer

Seed

Stomach ache

Maceration

Herb 0.54

Whole plant Wounds

Poultice applied to woun

Oral

Oral

Oral

Herb 0.78

Ziziphus spina-christi (L) Desf., Rhamanaceae, ZS/S18

Mayk

Bulb

Wounds

Poultice applied to wound

Leaf

Urinary tract infections Infusion

Oral

Oral

Ora

Oral

Oral

Oral

Note: * Purchased from local market

Tree

Topical 


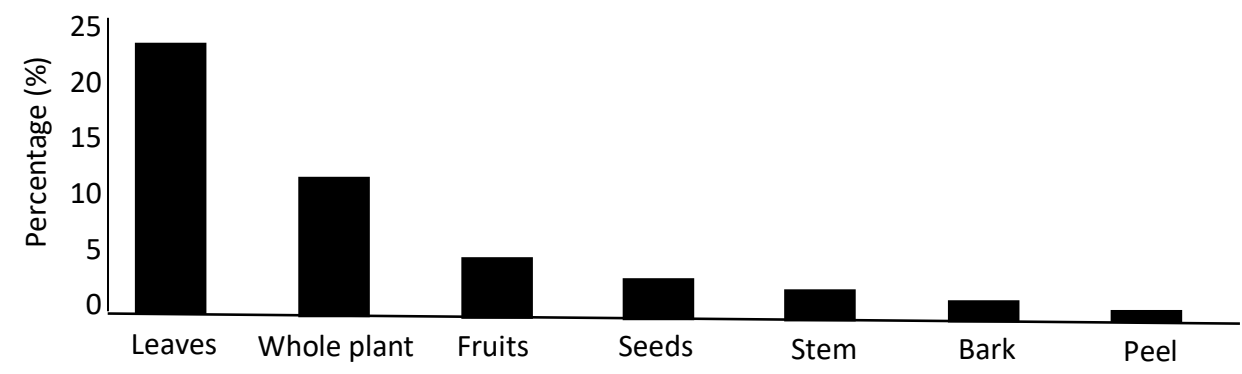

Figure 2. Percentage of plant part used

Table 5. Diseases categories and preferred species application by informant consensus factor (ICF) and fidelity level (FL)

\begin{tabular}{|c|c|c|c|c|c|c|}
\hline Ailment category & Nt & Nur & ICF & Preferred species & Application & FL \\
\hline Respiratory system diseases & 9 & 63 & 0.87 & Psidium guajava & Tuberculosis and cough & $91 \%$ \\
\hline $\begin{array}{l}\text { Cardiovascular system and } \\
\text { hematological disorders }\end{array}$ & 8 & 68 & 0.89 & Oxalis anthelmintica & Anemia & $92 \%$ \\
\hline Digestive system disorders & 12 & 115 & 0.90 & $\begin{array}{l}\text { Coriandrum sativum } \\
\text { Solenostemma argel } \\
\text { Ocimum basilicum }\end{array}$ & $\begin{array}{l}\text { Dysentery } \\
\text { Stomachache } \\
\text { Jaundice }\end{array}$ & $\begin{array}{l}80 \% \\
75 \% \\
70 \%\end{array}$ \\
\hline Genitourinary system disorders & 5 & 48 & 0.91 & Artemisia absinthium & Urinary tractinfections & $60 \%$ \\
\hline Infections/infestations & 12 & 38 & 0.70 & Tamarindus indica & Malaria & $80 \%$ \\
\hline Endocrinological system (diabetes) & 3 & 33 & 0.94 & Acacia seyal & Diabetes & $40 \%$ \\
\hline Skin diseases & 18 & 120 & 0.86 & $\begin{array}{l}\text { Aloe sinkatana } \\
\text { Parmotrema ultralucens }\end{array}$ & $\begin{array}{l}\text { Wounds } \\
\text { Skin allergies and sore }\end{array}$ & $\begin{array}{l}88 \% \\
80 \%\end{array}$ \\
\hline Musculoskeletal system & 2 & 6 & 0.80 & Euphorbia aegyptiaca & Rheumatism & $67 \%$ \\
\hline Growths & 1 & 53 & 1 & Withania somnifera & Breast inflammation and cancer & $90 \%$ \\
\hline Pain & 5 & 24 & 0.826 & $\begin{array}{l}\text { Aloe sinkatana } \\
\text { Fagonia indica }\end{array}$ & $\begin{array}{l}\text { Headache } \\
\text { Toothache }\end{array}$ & $\begin{array}{l}30 \% \\
62 \%\end{array}$ \\
\hline
\end{tabular}

Respiratory system diseases: cough, asthma, and tuberculosis. Cardiovascular system and hematological disorders: anemia, hypertension, hemophilia, and bleeding. Digestive system disorders: stomachache, diarrhea, dysentery, constipation, ulcer, and jaundice. Genitourinary system disorders: urinary tract infections, kidney disorders, syphilis, and gonorrhea. Infections/infestations: malaria, fever, bilharzia and gum inflammation. Endocrinological system: diabetes. Note: in diseases: skin allergy, wounds, sores, blemishes, rashes, and eczema. Musculoskeletal system: rheumatism. Growths: cancer. Pain: headache and toothache. Nt, number of taxa; Nur, number of use reports

Table 4. Mode of preparations of medicinal plants by the traditional healers

\begin{tabular}{llll}
\hline Oral (68\%) & \multicolumn{3}{c}{ Topical (32\%) } \\
\hline Maceration & $15(30 \%)$ & Powder & $13(54 \%)$ \\
Infusion & $22(44 \%)$ & Poultice & $6(25 \%)$ \\
Decoction & $8(16 \%)$ & Smoke & $2(8 \%)$ \\
Powder/latex/eaten raw & $5(10 \%)$ & Bath/mouth rinsing & $3(13 \%)$ \\
\hline
\end{tabular}

\section{Use value (UV), informant consensus factor (ICF) and fidelity level (FL)}

Culture, ethnicity, religion, and geographical location largely determine the traditional use of the medicinal plants. According to Table 2 the most commonly used species is Adansonia digitata with a UV of 0.89 , followed by Pancratium tortuosum (0.88), Azadirachta indica (0.83), and Jatropha curcas and Psidium guajava (0.81) each. Furthermore, in order to determine the ICF based on their application for different ailments the plants in the study area were assembled into ten categories.
Accordingly, an ICF value of 1 was obtained for the category of abnormalities, representing the highest value, followed by metabolic conditions (diabetes) (0.94), skin conditions (0.91), genitourinary disorders $(0.90)$ and digestive ailments $(0.90)$ (Table 5). Furthermore, fidelity level (FL) values were provided for the most important plant species in each ailment category where calculation was based on the information from four or more informants relevant to the treatment of specific disorders. Accordingly, the FL for Oxalis anthelmintica, used to treat anemia, was 92\%, followed by Psidium guajava (91\%) for treating tuberculosis and cough, Withania somnifera $(90 \%)$ for treating breast inflammation and cancer and by Aloe sinkatana $(88 \%)$ for wound treatment (Table 5).

\section{Discussion}

The chosen study area is unique within its surroundings in view of the significant difference in its climate and vegetation, comprising species representative of East African highland Afromontane and Mediterranean floras (Bullela and Ingrouille 1989). Regarding the prevalence of 
medicinal plant species in the region, the highest number is recorded for Euphorbiaceae followed by Leguminosae. This is in contrast to the ethnobotanical studies from other regions of Sudan where Leguminosae is the most reported as the family of highest prevalence (Musa et al. 2011; Suleiman 2015; Issa et al. 2018). However, Euphorbia with its vast diversity of biotopes plays a major role in some communities particularly in the disturbed and severely grazed mountain steppes (Pahlevani et al. 2015). Most of the informants used to gather plants from the wild, being easily accessible, with the perception that such plants have a higher level of curing effect than the cultivated ones. By virtue of the high geographical altitude, the habitat dictates the dominance of herbs over shrubs and trees (Table 3). Here, the use of leaves top the list followed by the whole plant and the fruit. The treatment of most ailments except skin diseases, or rheumatism, and toothache was through oral administration. Potions were mainly prepared by infusion and maceration as the healers are aware of the destructive effect of excessive heating (Table 2).

Considering the reliability index, ICF, the overall category data index $(0.70-1.00)$ indicated a high level of compatibility for the number of taxa with their corresponding application for different ailments by the healers in the study area (Table 5). Assessing the data for the categories when both UV and FL are considered, a high level includes the plants species Oxalis anthelmintica and Psidium guajava; the first, with a high UV of 0.77 and FL of $92 \%$, and highest preference in the treatment of anemia of the hematological disorders category, while the second, with UV 0.82 and FL 91\%, was the most preferred in the treatment of tuberculosis and cough of the respiratory system diseases category. It was also noted that some plants with low UV values but high FL values were in use by local healers as in the case of Withania somnifera (UV 0.14, FL 90) and Parmotrema ultralucens (UV 0.32, FL 80). Regarding the general status of vegetation in the study area, it is noteworthy that the ecosystem was impacted by bouts of drought leading to massive loss of perennial trees and a dwindling vegetation cover subjected to overgrazing and erosion (Vetaas et al. 2012), with widespread malnutrition and disease outbreaks. Consequent upon that the healers meticulously selected plants for treatment of specific disorders as in the case of Withania somnifera and Parmotrema ultralucens for breast cancer and skin conditions, respectively (Boadu and Asase 2017). As such, the situation reflects the rarity of species and an increasing threat to others like Aloe sinkatana, Pancratium tortuosum, and Urginea grandiflora as a consequence of the massive collecting for profit and study purposes.

A number of the plants in the present study according to their local use show pharmacological properties which tally with the published data for the same species from different areas. For instance certain parts of Withania somnifera as well as isolates such as withanolides, withaferins, withanone, and withanosides which have been reported to have antitumor activity towards cancer cell lines (Rai et al. 2016). It was also found that the anti glycemic activity of Artemisia absinthium in type II diabetes subjects, significantly reduced fasting serum glucose level (Hassan et al. 2018). Furthermore, the Kalanchoe glaucescens even though not proven to have antidiabetic effect, may yet help alleviate type II diabetes complications through its antioxidant activity (Dal and Sigrist 2016, Adam et al. 2018). Moreover, to add to the therapeutic/nutritional role of plants is the effectiveness of Azadirachta indica leaf and seed extracts against chloroquine-resistant strains of malaria plasmodium species (Alzohairy 2016; Habluetzel et al. 2019). Besides the purely nutritional role of Grewia tenax it is loaded with iron (Aboagarib et al. 2014). The analysis of Solanum schimperianum has revealed that it is a source of powerful antibacterial components against Bacillus subtilis and Staphylococcus aureus (Al-Oqaila et al. 2012; Fadl et al. 2017).

An important concern in the therapeutic use of plants is their toxic side effect, as is in the case with commonly administered plant medicines in the study area and generally in Sudan. Among the plants established to be toxic and cancerogenic is Aristolochia bracteolata indigenous to Sudan, due to its content of aristolochic acids, which called for strict control on the use of the plant (Abdelgadir et al. 2011). The widespread use of the medicinal plants in the study area and Sudan, in general, raises serious issues in regard to their toxic side effects. Plant components may vary according to the stage of growth, area season, and soil, and so does their bioactivity. Therefore, it is imperative that measures are put in place to ensure safety of use and by raising the awareness of the healers to this. There is also an urgent need for the establishment of governmental bodies to oversee and direct their us Active efforts by local governmental bodies could put in place plans in coordination with the population for selection and natural propagation of safer plants under advice of specialized scientific institutions.

The study area of Erkowit and Sinkat has a variety of plants used medicinally by local healers based on traditional knowledge with a high level of agreement for use in different conditions. However, the population of highly potent plants is decreasing, due to environmental and human factors that are leading to the loss of their natural habitat. To conserve the medicinal plant species and their diversity in the study area, an appropriate educational plan must be set up, with the local population to promote understanding of the endangerment and protection of these species. A positive approach consists of establishment of ex-situ medicinal gardens such in which the local population is mobilized. Also, in-situ conservation of the highly useful and depleting species could be achieved by propagating, reintroducing, regularly monitoring, and evaluating practices. The reported medicinal plants need to be systematically screened through phytochemical and pharmacological study for potential bioactive compounds which could further be used for designing drugs that will promote the development and expansion of pharmaceutical and herbal industries within Sudan. There is a concern about the toxicity of certain plants which calls for attention and organized approach to raise awareness of the healers and for streamlining of the gathering and the use of the local medicinal plants. 


\section{ACKNOWLEDGEMENTS}

We would like to thank all the traditional healers and local people from the study area for their cooperation, sharing their knowledge and hospitality.

\section{REFERENCES}

Abdelgadir AA, Ahmed EM, Eltohami MS. 2011. Isolation, characterization and quantity determination of aristolochic acids, toxic compounds in Aristolochia bracteolata L. Environ Health Insights 5: 1-8. DOI: 10.4137/EHI.S6292.

Aboagarib EAA, Yang R, Hua X, Siddeeg A. 2014. Chemical compositions, nutritional properties and volatile compounds of guddaim (Grewia tenax. Forssk) fiori fruits. J Food Nutr Res 2 (4) 187-192. DOI: $10.12691 /$ jfnr-2-4-9

Adam M, Elhassan GOM, Yagi S, Senol FS, Orhan IE, Ahmed A, Efferth T. 2018. In Vitro antioxidant and cytotoxic achical altitudetivities of 18 plants from the Erkowit region, Eastern Sudan. Nat Prod Bioprospecting 8: 97-105. DOI: 10.1007/s13659-018-0155-0

Al-Oqaila M, Hassan WHB, Ahmad MS, Al-Rehaily AJ. 2012. Phytochemical and biological studies of Solanum schimperianum Hochst. Saudi Pharm J 20: 371-379. DOI: 10.1016/j.jsps.2012.05.010

Alzohairy MA. 2016. Therapeutics role of Azadirachta indica (Neem) and their active constituents in disease prevention and treatment. EvidBased Complement Altern Med. DOI:10.1155/2016/7382506.

Bullela A, Ingrouille M. 1989. The mist oasis of Erkwit. Plants Today: 2022.

Bunalema L, Obakiro S, Tabuti JR, Waako P. 2014. Knowledge on plants used traditionally in the treatment of tuberculosis in Uganda. J Ethnopharmacol 151 (2): 999-1004, DOI: 10.1016/j.jep.2013.12.020.

Dal S, Sigrist S. 2016. The protective effect of antioxidants consumption on diabetes and vascular complications. Diseases 4: 24. DOI: 10.3390/diseases4030024.

Darbyshire I, Kordofani M, Farag I, Candiga R, Pickering H. 2015. The Plants of Sudan and South Sudan: An annotated checklist. University of Chicago Press, Chicago.

El-Ghazali GEB. 1986. Medicinal plants of Sudan. Part I. Medicinal plants of Erkowit. Medicinal and Aromatic Plants Institute. National Council for Research, Khartoum.

Elamin HM. 1990. Trees and shrubs of Sudan. Ithaca Press, Exeter, U.K.

Fadl AN, Voynikov Y, Gevrenova R, Schohn H, Tzanova T, Yagi S, Thomas J, Mignard B, Ahmed AAA, El Siddig MA, Spina R, Laurain-Mattar D. 2017. Antibacterial, antiproliferative and antioxidant activity of leaf extracts of selected Solanaceae species. S Afr J Bot 112: 368-374. DOI: 10.1016/j.sajb.2017.06.016

Faruque MO, Uddin SB, Barlow JW, Hu X. 2018. Quantitative ethnobotany of medicinal plants used by indigenous communities in the Bandarban district of Bangladesh. Front Pharmacol 9: 40. DOI:10.3389/fphar.2018.00040

Friedman J, Yaniv Z, Dafni A, Palewitch D. 1986. A preliminary classification of the healing potential of medicinal plants, based on rational analysis of an ethnopharmacological field survey among Bedouins in the Negev desert, Israel. J Ethnopharmacol 16: 275-287.

Boadu AA, Asase A. 2017. Documentation of herbal medicines used for the treatment and management of human diseases by some communities in Southern Ghana. Evid-Based Complement Altern Med. DOI: $10.1155 / 2017 / 3043061$.

Hassan M, Niazi AT, Khan S, Gul F. 2018. Antidiabetic and antihyperlipidemic effects of Artemisia absinthium L., Citrullus colocynthis (L.) Schrad. and Gymnema sylvestre (Retz.) R.Br. ex Sm. on type II diabetes hyperlipidemic patients. Indian J Tradit Know 17 (2): 233-239.

Habluetzel A, Pinto B, Tapanelli S, Nkouangang J, Saviozzi M, Chianese G, Lopatriello A, Tenoh AR, Yerbanga RS, Taglialatela-Scafati O, Esposito F, Bruschi F. 2019. Effects of Azadirachta indica seed kernel extract on early erythrocytic schizogony of Plasmodium berghei and pro-inflammatory response in inbred mice. Malar J 18: 35. DOI:10.1186/s12936-019-2671-8.

Hutchinson J, Dalziel JM, Keay RWJ, Nigel Hepper F. 2014. Flora of West Tropical Africa. Royal Botanic Gardens Kew, London.

Issa TO, Mohamed YS, Yagi S, Ahmed RH, Najeeb TM, Makhawi AM, Khider TO. 2018. Ethnobotanical investigation on medicinal plants in Algoz area (South Kordofan), Sudan. J Ethnobiol Ethnomed 14: 31. DOI: 10.1186/s13002-018-0230-y

Khalid H, Abdalla WE, Abdelgadir H. 2012. Gems from traditional northAfrican medicine: medicinal and aromatic plants from Sudan. Nat Prod Bioprospect 2: 92-103. DOI: 10.1007/s13659-012-0015-2.

Karar MG, Kuhnert N. 2017. Herbal drugs from Sudan: Traditional uses and phytoconstituents. Phoog Rev 11: 83-103. DOI:10.4103/phrev.phrev_15_15.

Manger L. 2001. Pastoralist-state relationships among the Hadendowa Beja of Eastern Sudan. Nomadic Peoples 5 (2): 21-48. DOI: $10.3167 / 082279401782310880$

Maydell HJV. 1990. Trees and shrubs of the Sahel, their characteristics and uses. GTZ Margraf, Eschborn.

Musa MS, Abdelrasool FE, Elsheikh EA, Ahmed LAMN, Mahmoud AE, Yagi SM. 2011. Ethnobotanical study of medicinal plants in the Blue Nile State, south-eastern Sudan. J Med Plant Res 5 (17): 4287-4297.

Pahlevani AH, Liede-Schumann S, Akhani H. 2015. Seed and capsule morphology of the Iranian perennial species of Euphorbia (Euphorbiaceae) and its phylogenetic application. Bot J Linn Soc 177: 335-377.

Rai M, Jogee PS, Agarkar G, dos Santos CA. 2016. Anticancer activities of Withania somnifera: Current research, formulations, and future $\begin{array}{lllll}\text { perspectives. Pharm Biol } 54 & \text { (2): 189-97. DOI: }\end{array}$ 10.3109/13880209.2015.1027778.

Srithi K, Balslev H, Wangpakapattanawong P, Srisanga P, Trisonthi C. 2009. Medicinal plant knowledge and its erosion among the Mien (Yao) in Northern Thailand. J Ethnopharmacol 123 (2): 335-342. DOI: $10.1016 /$ j.jep.2009.02.035

Suleiman MHA. 2015. An ethnobotanical survey of medicinal plants used by communities of Northern Kordofan region, Sudan. J Ethnopharmacol 176 (24): 232-242. DOI:10.1016/j.jep.2015.10.039

Trotter RT, Logan MH. 1986. Informants consensus: a new approach for identifying potentially effective medicinal plants. In: Etkin NL (ed) Plants in Indigenous Medicine and Diet. Bedford Hills, NY, 91-112, USA.

Vetaas OR, Salih E, Jurasinski G. 2012. Vegetation changes in the Red Sea Hills: from mist oasis to arid shrub. Plant Ecol Divers 5 (4): 527539. DOI:10.1080/17550874.2012.749954

World Population Prospects. 2017. United Nations Department of Economic and Social Affairs, Population Division. The 2017 Revision, Key Findings and Advance Tables. Working Paper No. $\mathrm{ESA} / \mathrm{P} / \mathrm{WP} / 248$ 